Jurnal Kependudukan Indonesia | Vol. 11 No. 1 Juni 2015 | 63-70

JURNAL KEPENDUDUKAN INDONESIA

p-ISSN : 1907-2902 (Print)

e-ISSN : 2502-8537 (Online)

\title{
CORRUPTION IN ACCESSING AND UTILIZING THE COMMON PROPERTY RESOURCES IN INDONESIA
}

\section{(KORUPSI DALAM MENGAKSES DAN MENGGUNAKAN SUMBERDAYA ALAM MILIK BERSAMA DI INDONESIA)}

\author{
Lengga Pradipta \\ Pusat Penelitian Kependudukan, Lembaga Ilmu Pengetahuan Indonesia \\ Korespondensi penulis: lengga.pradipta@gmail.com
}

\begin{abstract}
Abstrak
Artikel ini mengkaji beberapa kasus korupsi yang berkaitan erat dengan pengelolaan sumberdaya alam, terutama dalam hal mengakses dan menggunakan sumberdaya alam milik bersama. Artikel ini ingin mengangkat persoalan krusial yaitu adanya kasus korupsi terhadap sumberdaya alam. Artikel ini menggunakan kerangka kerja berupa 'Sistem SocioEkologis', yang akan memberikan penjelasan tentang keterkaitan karakteristik ekologis atau alami ke dalam sistem sosial dan hukum. Selanjutnya, kerangka kerja ini menjelaskan tentang bagaimana masalah akan diselesaikan dan apa saja tindakan serta peraturan yang akan diterapkan dalam mengatasi masalah ini. Sumber data yang digunakan adalah data makro ditingkat nasional yaitu peraturan perundangan mengenai sumberdaya alam dan lingkungan di Indonesia dan didukung kasus di Sumatra Barat, Kabupaten Pasaman Barat. Data didapatkan dengan cara melakukan wawancara mendalam dengan penduduk lokal di sekitar perkebunan sawit. Korupsi dalam konteks pengelolaan sumberdaya alam milik bersama akan membawa banyak kerugian pada masyarakat dan negara karena akan menyebabkan semakin berkurangnya sumberdaya. Tentunya secara keseluruhan, pemberantasan korupsi bukan hanya menjadi tanggung jawab masyarakat dan sektor swasta, tapi juga sangat membutuhkan peran serta pemerintah dan pembuat kebijakan sebagai pemangku kepentingan utama..
\end{abstract}

Kata Kunci: Korupsi, Pengelolaan Sumberdaya Alam, Sumberdaya Alam Milik Bersama

\begin{abstract}
This article reviews corruption cases that are associated with natural resources management, especially in accessing and utilizing common property resources in Indonesia. A crucial fact about to highlight in this article is corruption case in natural resource. This article applies social-ecological systems (SES) framework to deliver a clear roadmap for incorporating more ecological or natural characteristics into studies that explores linkage social and legal systems. The framework therefore considers how problems are defined and how action and policy are formulated to deal with these problems. This article studies macro data in National level, the law on natural resource and environment in Indonesia where the case is occurred in West Pasaman. The case in West Pasaman is the evidence based. The data is gathered by interviewing local people who live around palm plantations in West Pasaman. Thus, this article is also linked with Indonesian regulation about environment and natural resources. Corruption in the context of managing common property resources brings many disadvantages to community and State because it will lead to the scarcity of resources. Overall, eradicating corruption is not only on the hands of community or private sectors, but also needs active involvement from government and policy-makers as the main stakeholders.
\end{abstract}

Keywords: Corruption, Natural Resources Management, Common Property Resources 


\section{INTRODUCTION}

Along with the rapid pace of globalization in recent decades, many stakeholders such as environmentalists, economists and policymakers put their concern on natural resources issues. Natural resources in Indonesia are State property resources ${ }^{1}$, it means that central government have responsibilities to enforce all activities regarding to access and utilize the resources. It is also stated in article 33 point 3 UUD 1945 which mentioned that any kind of natural resources controlled by the State and will be used for the prosperity of the nation ${ }^{2}$.

However, even when the regulation is well defined, the condition and factual case may not be the same. Many problems arise due to the inability of the governments to enforce regulations for natural resources. There are many research findings show that corruption is strongly related to the over-exploitation of natural resources. Thus, it has become evident that natural resources issue is a growing problem that leads to corruption. Corruption itself has been described as an evil with ecological implications (Sundstrom, 2013). For example, many tropical forests are State property, but in fact, they are over-exploited because illegal-logging still remained and law enforcement still has many obstacles. In Sumatra Island, West Pasaman is one of the targeted areas for forest conversion. Community forest has been converted to palm plantation since New Order era, and the condition is getting worse through times. At the other side, governments seem to have lack of willingness to apply severe penalties for the user who exploited natural resources. By this situation, we may assume that there are lots of corruptions in the context of managing the natural resources.

This article will describe about the effect of corruption, which related to environment and natural resources management. Moreover, it will be focused on the community because they hold double positions, first; as the main user of natural resources and second; as the victim of corruption. By these reasons, they have to get deep understanding about the nuances of corruption in accessing and utilizing natural resources. Given these ideas, the aim of this article is to explore the socialecological systems (SES), which link between social and ecological system of resources users with the governance arrangements.

\footnotetext{
1 As opposed to common access and common property resources, which suffer from the standard 'tragedy of the comons' problem leading to over-exploitation resources. See Heltberg (2002) for a nice survey of different property rights regimes regarding natural resources and their consequences.
}

The rest of the article is organized as follows; section 2 will discuss about previous research on how corruption affects common property resources. Section 3 will highlight the corruption and regulations in the context of legal sphere. Furthermore, section 4 will describe the investigations and findings related to corruption in common property resources. At the last section this article will be summarized.

\section{CORRUPTION AND THE COMMON PROPERTY RESOURCES}

Corruption can be defined as cultural phenomena in our society, because it depends on how a society understands the rules and what constitutes a deviation (Melgar, 2009). Frankly, it also depends on personal values and norms. The Latin proverbs quis custodiet ipsos custodies imply the satirical question; who will guard the guards? It reminds us that we may appoint officials or governments to guard our rights, but then we should be aware of their action, whether they are abusing the power they have or not. In this condition, we cannot avoid the dilemma that arises between society and governments.

The Latin proverbs, which mentioned above, are very similar to the Hardin's findings. Hardin defined that our biggest challenge is to invent the corrective feedbacks which are needed to keep the guard honest. Thus, since it always happened from time to time, we have to establish a solution to legitimate the need of authority of both guards and the corrective feedbacks (Hardin, 1968). This finding became a breakthrough among the researchers and they always used this theory to solve any cases, which related to natural resources overexploitation. Subsequently, this concern also led many stakeholders to have a serious effort in minimizing the cases in natural resources such as; forest depletion, land degradation and water crises.

Not all countries have rich biodiversity and natural resources. Unfortunately, most of the country, which endowed with natural resources, is not classified as high-income countries. Indonesia could be one of the examples, although Indonesia has enormous natural resources, most people are still trapped in poverty.

\footnotetext{
${ }^{2}$ UUD 1945, Article 33 point 3, "bumi, air, dan kekayaan alam yang terkandung di dalamnya dikuasai oleh negara dan dipergunakan untuk sebesar-besarnya kemakmuran rakyat”.
} 
This condition is captured by many scholars; one of them is Eggert (2001) who puts his concern on the relation of economic sustainability and community welfare. He has a high-curiosity about the natural resources in Indonesia; he implies that natural resources could be a 'gift' or even a 'curse' for this country. Because he assumes that natural resources sometimes do not bring prosperity to people, especially if there is a misuse action on it. This theory leads to a statement, "a curse in natural resources happened because the regulation is not appropriate", and obviously this situation need to be revamped.

Discussing about natural resources also means discussed about common property resources, or mostly called as common pool resources (CPRs). Common pool resources can be explained as a resource system where it is costly to exclude potential beneficiaries, but one person's use subtracts resource units from those available to others. Most ecological systems used by multiple individuals can be classified as common-pool resources. Common-pool resources generate finite quantities of resource units. One person's harvesting of resource units from a common-pool resource subtracts from the quantity of resource units available to others (Ostrom, 2007). The example of common pool resources include both natural and human-made systems such as rivers, lands and forests.

Many literatures presented about common pool resources, especially literature which guides us to understand the relation about common pool resources and how to revamp the regulations and governance systems. Environmentalists, economists and policymakers sometimes defined the users as the victim of resources because they are unable to exclude themselves from the processes of overuse and potential destruction of the system. In spite of the previous fact, the users also facing a social dilemma, which actually indicates them to have cooperation with other stakeholders, so all burdens that rise in common pool resources could be bear together.

\section{CORRUPTION AND REGULATIONS IN INDONESIA}

Corruption in Indonesia have 'entrenched' for decades, before and after independence, in the era of the Old Order, New Order, and still occurred until the Reformation Era. Many efforts have been established to eradicate corruption, but the results are still not sufficient. Historical experts in Indonesia are not interested to conduct their studies on corruption. They are more interested in political and social history, whereas the impact of corruption can influence the political sphere and regulations.

The exploitation of Indonesia's natural resources since the 1960s has brought economic benefits to the country, but at the same time damaged the natural environment and society in resource-rich areas in a way that fosters social tensions and has led to violent conflict. Indonesia needs to manage its natural resources in a way that is fairer and more sustainable than in the past.

In reformation era, President Habibie has issued Act no. 28/1999 about Clean Government which means free from corruption, collusion and nepotism. However, the implementation of this Act faces many obstacles. Furthermore, this Act is also supported by the Act no. 31/1999 about Eradicating Corruption, this Act then amended to Act no. 20/2001 but still it cannot combat the corruption in Indonesia. The most tremendous situation happened under President Yudhoyono era, especially in the legislative council which they abused their own authority by issuing regulations that is always contradictive to people's welfare. By this fact, we may conclude that corruption hampers development process, poverty alleviation and destruct natural resources.

Regulation or legal reforms serve as a useful prism to view some of the persisting dilemmas that affect the overall enterprise of common-pool resources management (Lindsay, 2004). Ironically, the rhetoric of community-based resources management is that it is usually has not been matched by action on the ground. This is mirrored in legal provisions that are often only pale reflections of the robust policy pronouncements from which they emerge. New policies frequently establish - and can serve to entrench - a continuing ambivalence on the part of governments about relinquishing or sharing real power, and vesting significant rights in local people.

At the same time, there is a gap between regulations and gigantic corruption in common pool resources. Corruption in common pool resources destroys local communities in many forms, social and ecological sustainability or even their livelihood condition. Conversely, there are no 'legal solutions' for such burdens, what they actually need are legal aspects which are more realistic and better mechanisms or methodologies that stand on their side. In a more concrete situation, corruption is charged to cause depletion of tangible resources, which is typical of a common pool resource. Corruption can lead to the bankrupting of the state or at least reduce its ability to provide public services effectively and efficiently. One might conceptualize the collective benefit here to be the 
percentage of the public purse allocated to the provision of services, and free riding-engaging in corrupt behavior-as reducing or depleting the capacity of the state to take care all citizens to its actual financial potential.

Furthermore, the root of the environmental problem is corruption in the management of common pool resources and it is intended to perpetuate control over natural resources both economically and politically. Corruption is not only detrimental to the country in terms of the state budget either through taxes or bribes in licensing, the shocking fact shown that the corruption in common pool resources sector has given bad impact to people's welfare and destroy the environmental quality which leads to ecological disaster. In the context of human rights, we have to ensure the State to protect, respect and fulfill their right to use the environment. Thus, the State is supposed to be in the frontline to urge corporate responsibility for crimes against the environment and humanity that has been conducted. It means, the State should not be subject to corporate power.

The crucial research problem guiding this article is thus how we can understand why the corruptibility authorities affect community as the users of common pool resources. In order to extract additional knowledge related to the above facts the following two questions need to be answered:

- Does the social ecological system (SES) framework support the people to manage their resources?

- Does corruption of both government and private stakeholders affect CPR users' willingness to comply with regulations?

Aiming to answer these two questions this article uses primary data from interviews with community in West Pasaman district. This case is chosen on the basis that the sector is governed by a regime with high levels of corruption. Moreover, if we are interested to apply the social-ecological systems (SES) in this topic, this case provides a deep investigation. Interviews are used since this is useful particularly for accessing individuals' perceptions. In-depth interviews were held with ten respondents, and they came from forest area in West Pasaman.

West Pasaman district is also chosen for the study because there are huge numbers of community forests converted into oil palm plantations. Based on the latest data from HuMa (2014) there are 4.777 hectares of forests converted into oil palm plantations. The existence of forest, which is supposed to be common pool resources gradually disappeared, and private stakeholders expanded their business into million hectares of oil palm plantation. Ironically, this action did not improve the economic condition of community. Every year West Pasaman is still categorized as "poor" and always subsidized by central government (Steni, 2013).

Hence, the interview processes were mostly performed in the respondent's residences and usually in Bahasa Indonesia and Bahasa Minang. They preferred to speak in both languages because not all respondents in West Pasaman originally came from West Sumatera Some clans such as Javanese and Bataknese also lived in that area. Surprisingly, they could explain at length on issues related to forestry regulations. Confidentiality was promised and sensitive information was discussed that put the researcher in the position of having to keep the promises of discretion to respondents rather than informing law agents of criminal acts.

\section{FINDINGS AND DISCUSSION}

This article began with the social and ecological systems as an assumption which can lead to good governance of common pool resources. In this phase, the analysis begins with an overview of social ecological systems (SES) framework - in West Pasaman district - and mainly focused on the management of common pool resources. Then it also addresses corruption cases in the government and private stakeholders sphere and how it will affect the people in that area. Finally, the findings and discussion will be summarized by outlining policy implications and further research in common pool resources in Indonesia.

\section{a. The Social Ecological Systems in the Context of Common Pool Resources}

As mentioned before, common pool resources (CPR) are resources in which; (i) consumption by one limits consumption by another and (ii) it is difficult to exclude people from them. More precisely, CPRs are resources that are limited and very difficult to manage with private property rights. The forests described in these cases are a classic example of common pool resources. Forests are limited resources, and it is difficult to keep them from being overexploited. The term "commons" is informally used to refer to public goods, common pool resources, or any area with uncertain property rights. Moreover, for analytical purposes it is very crucial to explain it more specific (Chou, 2010). 
However important the commons are to the lives of millions of the poor, they are often neglected by State policies. Historically, the commons were either not governed well or not governed at all. In general, the resources were just there and they were often seen as under the nebulous management of the unseen State and could be accessed by anyone who might find them useful. The appropriation was often uncontrolled since the resources considered abundant. The risk of this assumption is the overexploitation and over-extraction of resources, and it is called 'the tragedy of the commons'.
To properly understand the nature of the SES at any point in time or space, the relationship between socioecological resilience, ecosystem change and politiceconomic processes must be examined. The argument here is that levels of socio-ecological resilience are primarily mediated by the nature, capacity and location of ecosystem management. This, in turn, is articulated by institutional capacity and by the ability, need and

volition to administer ecological goods and services, particularly forests.

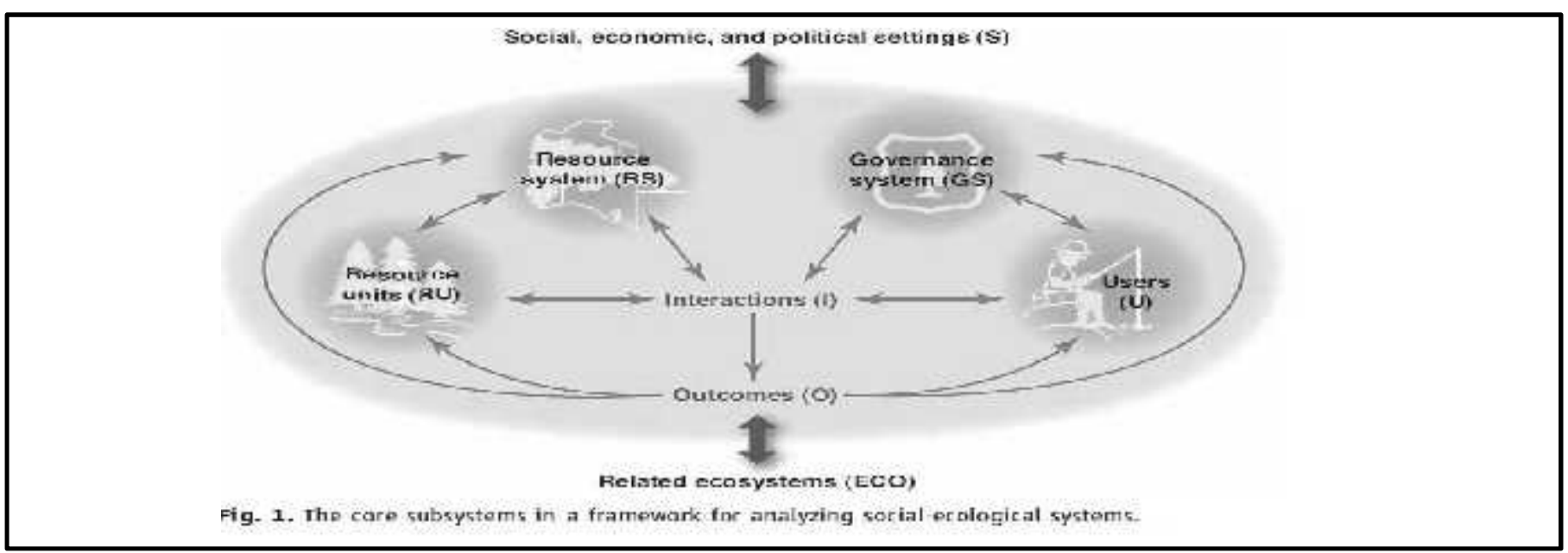

Many scholars tried to find a well-established formula to save the common pool resources from destruction. The idea to save the resources then brought them to create a new framework called social-ecological systems (SES). Without any objection, this breakthrough gave a clear roadmap for incorporating more ecological or natural characteristics into studies exploring linked social and legal systems. This article tries to develop the concept of social-ecological systems. As we all know, it is used to describe ecosystem functionality as derived from a set of natural and socio-economic processes that cannot be separated from one another as one impact and amends the other. It can be assumed as interdisciplinary analysis.

From the figure, we can see that SES is framework which provides the equal attention to biophysical and ecological foundations of institutional systems. Nowadays, it exists as classification systems that highlight all major variables, and people have to keep it on their mind that need to manage both sides, the human behavior and natural resources. Subsequently, we may imply that this system is characterized by variable of human and physical inputs, processes and outputs. The nature of the processes is as such that it is hard to maintain human or physical discretion as all processes interact and impact on each other (Flint, 2008).
The Social Ecological System (SES) framework obviously supports people around the forest in managing their resources. SES is based on assumptions about human behavior or ecological dynamics that are uncertain but potentially have a substantial effect on model outcomes. Moreover, lack of knowledge on the decision making process of human agents, on how future benefits are valued, on how actors learn, or on the processes that are considered relevant for the dynamics of a natural resource, such as the reproduction and growth of a natural resource. This is very important in an interdisciplinary context where theories and assumptions that stem from different disciplinary backgrounds are often unknown to researchers from other disciplines.

In this case, they learned to manage their forests in a proper way. If this framework is applied, the level of resources loss can be decreased. The management of any resources needs a balance between the interests of various stakeholders. In local management settings, the proper balance between local choice and the broader public interest may be extremely contested. The arguments for greater local choice may be more or less compelling depending on a wide number of variables, ranging from the nature of the resource, to the 
externalities of resource extraction, to the capacity of the community. Hence, it is difficult in the abstract to evaluate social and legal in terms of the extent to which it unduly limits local decision making.

Deciding where local choice should prevail and where it can legitimately be trumped by wider interests has seldom been given the reflection it deserves in the design of SES frameworks. What is striking when one looks at even some of the most progressive new framework supporting community-based management is how jealously government holds to the decisionmaking function. An interesting fact here is that community needs to manage their own resources, and governments have to support their capacity by giving education, not by conducting corruption.

\section{b. Corruption Hampers the Enforcement of Environmental Regulations}

In Indonesia, there are many legal instruments regarding to environment were established since reformation era. The regulation about forestry is implied by Act. No 41, 1999. Although this regulation was made decades after Indonesia's independence, it was still imperfect because it did not consider the existences of indigenous people in Indonesia. Since then, it has raised many contras. Indigenous people, environmentalists and green activists tried to propose a judicial review to Constitutional Court.

Besides forest regulation, Indonesia's government also produced a regulation about protecting and managing environmental resources, which reflected in Act. No 32, 2009. However, this regulation has many drawbacks, especially on the involvement of community in managing their resources. Article 26 point (2) stated that: "community involvement should be based on the principle of transparency and complete information and should be notified before the environment activities carried out". In this article, there is no complete information about the format and what is the legal remedy over it. Furthermore, the similar condition can be seen in article (4), which also makes people ambiguous to interpret the regulations. In article (4) is stated: "community, as referred to paragraph (1) may propose their objection to environmental impact assessment (EIA) documents" this statement did not follow by clear explanation and it causes the confusion about what kind of community rejects the document, it will destroy the rights of community in the development process.

Moreover, the Act No 32, 2009 has not been fullyunderstood by community. The majorities of
Indonesian people do not understand the substances of environmental regulations because the structure is too academic and hardly touch rural people's knowledge. In practice, this regulation is useless and can only be used by minorities of people who have rational thinking. Actually many things may affect the law enforcement,. The Act is very crucial in this issue, but the importance of other factors such as communityawareness cannot be denied.

This condition is getting worse because of intellectual stakeholders such as government and private sectors are also doing corruption over the resources. Although the regulations combating corruption has been implied in Act no. 20, 2001 but still they are trying to get enormous profit and neglected the needs of community. This law enforcement does not go easy. There are several barriers that are often encountered, in particular, it is very difficult to find experts in forestry issue and greenlawyer who have concerns on environment. Moreover, the geographical conditions of common pool resources are difficult to reach is another big obstacle.

For example, in West Sumatera, there are million hectares of forests but it does not bring prosperity to the people. According to Statistics Indonesia, in 2011, the number of poor people in West Sumatra is about 442.090. Approximately, $68 \%$ of that number lives in rural areas or villages. This atmosphere does not give significant changes in governance level, where corruption occurred even more severe. West Sumatera is classified as a province with a significant level of corruption. For example, 43 people of legislative council became convicted of corruption cases (http://www.antikorupsi.org).

As mentioned before, West Pasaman is a district that has million hectares of forests in West Sumatera. But now the forests in West Pasaman are altered into oil palm plantation. These oil palm plantations are established mostly by large-scale private stakeholders and they just ignored the prosperity of the indigenous people. This action, of course, did not improve the economic condition of community and until now West Pasaman is still categorized as a poor and isolated district. By these facts we can see that corruption and overexploitation of resources are occurred in both government and private sectors. This situation is very pathetic. Government had created the natural resources sector for a classic open access commons or properties - but at the same time they are also denying ownership of local people, it makes natural resources have become a free-for-all and a 'tragedy of the commons' is unfortunately took place. 
The accounts above indicate that corruption affect common pool resources. Consequently, the community around the forests will be influenced by this action and it affects their attitudes to regulations. In Kinali, a subdistrict in West Pasaman, a respondent revealed a shocking fact;

"There has been a scandal related to our
forests, 'Niniak Mamak' are agreed when
private sectors make the (oil) palm
plantation in our forests and they got some
compensation through that agreement, but
unfortunately, Niniak Mamak do not want
to allocate that compensation for the
prosperity of the clans".

This cynical opinion came out from a key-informant in that area. It indicates that corruption has spread from the highest level to the lowest. This condition surely decreases people's willingness to comply with regulations.

This study contributes insights for scholars and practitioners interested in forests as common pool resources, illuminating how legal aspects need to be considered. However, some aspects of these findings can be expanded to other setting such as social and ecological systems. Being a regime with complex context and a corrupt enforcing authority, the forest does inhibit special features. Therefore, the findings from this article could arguably be expanded to have relevance also in other corrupt settings. Though the respondents were not large in numbers, they were selected in order to maximize their diversity in relevant aspects. A next step for researchers could be to broaden the sample, including CPR users from other settings.

\section{CONCLUSIONS}

The aim in this article is to develop understanding of why corruption affects common pool resource (CPR) users' to regulations and, more specifically, to explore the social-ecological systems (SES) in the context of common pool resources. Accounts from confidential interviews with forests community illustrate how the widespread corruption within the enforcing authority makes it into tremendous effects.

The causes of corruption in the environmental sector includes typical causes attributed to any other sectors: insufficient legislation, lack of respect for the rule of law, weak democracy, wide authority given to public officials, minimal accountability and transparency, poor enforcement, low levels of professionalism, and perverse incentives. In addition, corruption in the environmental sector is also triggered by conflicts between private interests in revenue that can be gained from environmental resources and public interests in a healthy environment. Strategies to address corruption in the environmental and natural resources sector include a combination of enforcement, prevention and awareness elements. For sustainability, anti-corruption efforts need to emphasize preventive reforms and public awareness components because these ultimately reduce the opportunities for corruption.

The article contributes to our theoretical understanding of the relationship between corruption and common pool resources in two distinctive ways. First, this study elucidates the complex frameworks of social and ecological system. It shows that an integrative or interdisciplinary solution can be an extraordinary formula to solve the cases about common pool resources. Secondly, results from this study illustrate how corruption hampers the effectiveness of regulations. In order to improve the effectiveness of regulations of natural resources in states where corruption is a widespread malady, policy-makers and practitioners have to improve the role of government in every sector. The findings from this study should serve as a reminder that corruption in forests - and common pool resources management in general - needs to be addressed with renewed and advance strength. To sum up, there is a crucial need of some legal experts who have experiences in legal and environmental fields to share and evaluate ideas and techniques about common pool resources.

\section{REFERENCES}

Chou, Chea. 2010. The Local Governance of Common Pool Resources: The Case of Irrigation Water in Cambodia. CDRI Working Papers No. 47. August 2010.

Eggert, Roderick G. 2001. Mining and Economic Sustainability: National Economies and Local Communities. International Institute for Environment and Development.

Flint, Lawrence S. 2008. Socio-Ecological Vulnerability and Resilience in an Arena of Rapid Environmental Change: Community Adaptation to Climate Variability in the Upper Zambezi Floodplain. Research Institute for Humanity and Nature (RIHN). June 2008.

\footnotetext{
3 Niniak Mamak is the elder and respected groups in Minangkabau terms.
} 
Hardin, Garrett. 1968. 'The Tragedy of The Commons' (1968) $162 \quad$ (3859), JSTOR, <http://cecs.wright.edu/ swang/cs409/Hardin.pdf> accessed on 12 May 2014.

Heltberg, Rasmus. 2002. "Property Rights and Natural Resource Management in Developing Countries". Journal of Economic Surveys. Vol 16, No 2, 2002. 189-214.

HuMa. 2014. Ruang Gerak Masyarakat dalam Mengontrol Perizinan Kelapa Sawit. HuMa and the Asia Foundation. Maret 2014.

Lindsay, Jonathan. 2004. Legal Framework and Access to Common Pool Resources. FAO Legal Papers Online \#39. September 2004.
Melgar, Natalia. 2009. 'The Perception of Corruption' (2009) $22 \quad$ (1), IJPOR <http://ijpor.oxfordjournals.org/content/22/1/120.ful 1> accessed on 11 May 2014.

Ostrom, Elinor. 2007. The Governance Challenge: Matching Institutions to the Structure of Social-Ecological Systems. Princeton University Press.

Steni, Bernadinus. 2013. Hak Masyarakat Atas Tanah dan Sumber Daya Alam Dalam Strategi REDD+. Perkumpulan HuMa Indonesia.

Sundstrom, Aksel. 2013.Corruption in the Commons: Why Bribery Hampers Enforcement of Environmental Regulations in South African Fisheries. International Journal of the Commons. Vol. 7, No. 2 August 2013. 454-472.

http://www.antikorupsi.org/id/content/43-mantan-anggotadprd-sumbar-segera-dieksekusi. Accessed on May 19,2014 